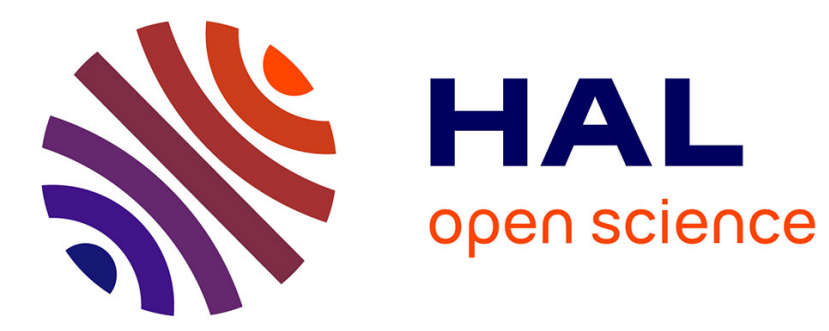

\title{
Mammalian Epididymal Proteome
}

Jean-Louis Dacheux, Clémence Belleannée, Russell Jones, Valérie Labas, Maya Belghazi, Benoît Guyonnet, Xavier Druart, Jean Luc Gatti, Françoise Dacheux

\section{- To cite this version:}

Jean-Louis Dacheux, Clémence Belleannée, Russell Jones, Valérie Labas, Maya Belghazi, et al.. Mammalian Epididymal Proteome. Molecular and Cellular Endocrinology, 2009, 306 (1-2), pp.45. 10.1016/j.mce.2009.03.007 . hal-00499124

\section{HAL Id: hal-00499124 https://hal.science/hal-00499124}

Submitted on 9 Jul 2010

HAL is a multi-disciplinary open access archive for the deposit and dissemination of scientific research documents, whether they are published or not. The documents may come from teaching and research institutions in France or abroad, or from public or private research centers.
L'archive ouverte pluridisciplinaire HAL, est destinée au dépôt et à la diffusion de documents scientifiques de niveau recherche, publiés ou non, émanant des établissements d'enseignement et de recherche français ou étrangers, des laboratoires publics ou privés. 


\section{Accepted Manuscript}

Title: Mammalian Epididymal Proteome

Authors: Jean-Louis Dacheux, Clémence Belleannée, Russell

Jones, Valérie Labas, Maya Belghazi, Benoît Guyonnet,

Xavier Druart, Jean Luc Gatti, Françoise Dacheux

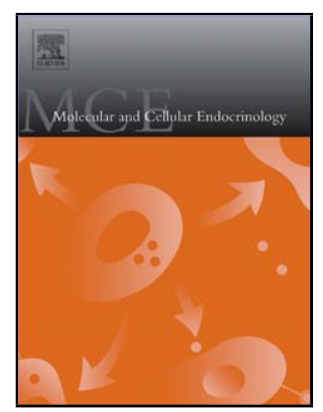

PII:

S0303-7207(09)00180-4

DOI: doi:10.1016/j.mce.2009.03.007

Reference:

MCE 7178

To appear in:

Molecular and Cellular Endocrinology

Received date: $\quad$ 15-11-2008

Revised date: 10-3-2009

Accepted date: $\quad$ 11-3-2009

Please cite this article as: Dacheux, J.-L., Belleannée, C., Jones, R., Labas, V., Belghazi, M., Guyonnet, B., Druart, X., Gatti, J.L., Dacheux, F., Mammalian Epididymal Proteome, Molecular and Cellular Endocrinology (2008), doi:10.1016/j.mce.2009.03.007

This is a PDF file of an unedited manuscript that has been accepted for publication. As a service to our customers we are providing this early version of the manuscript. The manuscript will undergo copyediting, typesetting, and review of the resulting proof before it is published in its final form. Please note that during the production process errors may be discovered which could affect the content, and all legal disclaimers that apply to the journal pertain. 


\section{Mammalian Epididymal Proteome}

Jean-Louis Dacheux ${ }^{(1)}$, Clémence Belleannée, Russell Jones ${ }^{(2)}$, Valérie Labas ${ }^{(3)}$, Maya Belghazi $^{(3)}$, Benoît Guyonnet, Xavier Druart, Jean Luc Gatti, Françoise Dacheux

INRA-CNRS 6175, Nouzilly, 37380, France ;

(2) The University of Newcastle, Newcastle, NSW, Australia.

(3) Service de Spectrométrie de Masse pour la Protéomique, INRA, Nouzilly, F.

Keys words: proteome, secretome, epididymis, sperm maturation

(1) Corresponding author: Jean Louis Dacheux, Tel: 332474279 49, Fax: 33247427743 jdacheux@tours.inra.fr, 


\section{Summary}

In all mammalian species, the final differentiation of the male germ cell occurs in the epididymal duct where the spermatozoa develop the ability to be motile and fertilize an ovum. Understanding of these biological processes is the key to understanding and controlling male fertility. Comparative studies between several mammals could be an informative approach to finding common sperm modifications which are not speciesspecific. The new global biological approaches such the transcriptomes and proteomes provide considerable information which can be used for such comparative approaches. This report summarizes our proteomic studies of the epididymis of several mammals, including humans.

\section{Introduction:}

Epididymal function is essential for the fertility of male mammals because their sperm are infertile when they leave the testes and only acquire the ability to fertilize an ovum during passage through the epididymides. It is also essential that the epididymides accumulate and store sperm as, depending upon species, it takes 0.5 to 2 days for the testes to produce the number of sperm in a normal ejaculate, and in a competitive mating system males may inseminate up to 50 females in a day (Jones, 1999;Jones et al., 2007). The efficacy of sperm storage in the epididymis is so high that fertile sperm can survive in an isolated epididymis for several days at $4^{\circ} \mathrm{C}$ (Guérin et al., 2003)

The epididymis is a very long duct which receives testicular sperm via the efferent ducts. In eutherian and marsupial mammals the duct is differentiated into about 6 structurally distinct segments, indicating a well developed division of labor. Although all mammals have an initial segment of the epididymis with distinctive characteristics, there is variation between species in the structure and extent of the different segments, suggesting some variation in post-testicular sperm maturation and storage (Jones, 2002:). The division of labor through the epididymis has been confirmed in studies of epididymal physiology and sperm modifications along the duct, and these findings have lead to the paradigm that the maturational changes in sperm in the epididymis are the result of sequential changes in their milieu, particularly the proteins secreted by the epididymal epithelium (Dacheux et al., 2003). In view of the variations in epididymides between species mentioned above, it is considered that there must be conserved aspects and variations between species in the changes in protein composition throughout the epididymis, presumably reflecting the occurrence and relative significance of sperm maturation and storage between species. This 
short review therefore compares our findings regarding the proteome and secretome of epididymal fluid in mammalian species: i.e. the stallion, ram, boar and human.

\section{Characteristics of intra luminal epididymal proteomes}

Most of the studies analyzing the proteins of epididymal fluids have been performed on samples obtained either from tubule micropuncture (Turner et al., 1995; Turner et al., 1999) or from microperfusion techniques (Druart et al., 1994; Syntin et al., 1996 ; Fouchecourt et al., 2000 ; Dacheux et al., 2006) The epididymal fluid provides a milieu for the gamete analogous to blood plasma providing a milieu for cell tissues. Due to the presence of the blood-testis and blood-epididymis barriers, most of the blood proteins are not found in epididymal plasma (albumin, transferrin and certain others being exceptions). In contrast to the stable concentration of blood plasma proteins, the protein concentration in epididymal fluid varies greatly along the duct: from $2-4 \mathrm{mg} / \mathrm{ml}$ in the initial segment of the epididymis, a maximum of $50-60 \mathrm{mg} / \mathrm{ml}$ in the distal caput and $20-30 \mathrm{mg} / \mathrm{ml}$ in the more distal regions of the organ (Fig 1C.). For most of the species studied, these variations in protein concentration follow the changes in water content of the fluid as assessed by changes in sperm concentration (Fig.1A).

Several hundred epididymal proteins have been described electrophoretically and some have been identified. There is a wide range of dynamics in the abundance of these proteins (probably around 10 orders of magnitude). About 15-20 proteins make up more than 60 to $80 \%$ of the total protein concentration. The most common proteins found are lactoferrin, procathepsin D, NCP2 (HE1, CTP, cholesterol transfer protein), GPX (glutathione

70 peroxidase), beta- $\mathrm{N}$-acetyl-hexosaminidase, mannosidase, galactosidase, PGDS (Prostaglandin D2 synthase), clusterin, CRISP (Cystein-rich secretory protein) and E-RAPB (epididymal retinoic acid-binding protein).

The protein composition changes continuously throughout the duct, independently of the protein concentration in the fluid. The concentrations of the major common proteins cited above vary between species (Fig. 2). Lactoferrin, mannosidase, PGDS and albumin are present in high concentrations in the stallion, boar, ram and human, respectively, but GPX and PGDS are virtually absent in humans and boar, respectively.

Most of the epididymal proteins are characterized by their numerous isoforms which result from their high degree of glycosylation. The $\mathrm{pI}$ of these multi isoforms can vary widely, ranging from $\mathrm{pH} 3$ to 8 for the same protein (i.e. RNase 10 in the boar, Fig. 3). The degree of glycosylation for the same protein can be different according to the epididymal 
region eg. clusterin and PGDS in the horse, where the number of isoforms is different between the anterior and the posterior part of the organ (Fig 3.), or RNase 10 (Train A) which is different between species for the boar and the ram (Fig 3).

\section{Dynamics of epididymal fluid proteomes}

The spatial changes in the composition of luminal proteins are the result of two opposite activities of the epithelium: protein secretion and protein absorption throughout the epididymal duct. In the anterior part of the epididymis, the epididymal fluid is composed of

90 a mixture of testicular and epididymal proteins. Most of the proteins originating from the testis, such as albumin, transferrin, testicular clusterin and PGDS (Fouchecourt et al., 2000) are reabsorbed in the efferent ducts (Clulow et al., 1994) The rapidity of their absorption is species-specific and generally almost all are absent in the posterior part of the epididymis, except in humans in which albumin and transferrin are still present in large quantities.

The epididymal epithelium has high protein synthesis and secretion activity, activity being high both in the rates of protein synthesis and secretion and in the variety of proteins secreted. The anterior part of the epididymis is the most active (Figs. 1B, 2). As for the protein concentration, from 70 to $80 \%$ of the secretome is composed of 10 to 20 of. the major secreted proteins present in the luminal fluid (Fig. 4). Most of the luminal proteins are secreted by the epithelium, but some, such as ACE, are released from the sperm surface by an unknown sheddase in an anterior part of the epididymis (Fig. 6) (Gatti et al., 1999; Metayer et al., 2002; Thimon et al., 2005).

Among the different proteins secreted, the same protein can be secreted in the same region of the epididymis in different species, for example PGDS, GPX and clusterin in the anterior part, and glucosidases in the middle part. Clusterin is secreted at a greater rate than the other proteins and can represent $30-40 \%$ of the all the proteins secreted. This clusterin can be sequentially secreted under different isoforms in different parts of the epididymis as in the stallion and the ram (Figs. 2, 3). Some highly secreted proteins are characteristic of a species, for example, lactoferrin in the stallion, PGDS and GPXin the ram and RNase 10,

110 mannosidase and hexosaminidase in the boar (Fig. 2).

In humans, in contrast to other species, few changes in pattern of protein secretion occur throughout the epididymis, a finding which correlates with the low degree of structural differentiation of the epididymal epithelium along the duct (Holstein, 1969).

Variations in luminal protein concentrations, controlled by secretory and absorption activites, are modulated for each species by the length of the epididymal duct involved in 
the two activities, i.e. the flow rate of the luminal fluid, enzyme degradation or the binding of protein on the sperm membrane. All these parameters differentially affect the concentrations of almost all proteins. Some are reabsorbed as soon as they are secreted and never reach high luminal concentrations, for example RNase 10 in the boar (Fig 5B)

120 (Castella et al., 2004), and several isoforms of clusterin in the stallion (Fig.3) (Fouchecourt et al., 2000). For most other proteins, concentrations are high in the region where they are secreted and gradually decrease in the following region, for example GPX and PGDS in different species (Figs.2, 5A). The concentrations of some other proteins increase throughout the epididymal duct, as for example lactoferrin in the stallion and hexosaminidase and mannosidase in the boar (Fig.2).

\section{Relationships between sperm maturation and epididymal proteome among species}

The most obvious and easily observed change in sperm directly related to acquisition of fertility is the activation of their flagella machinery. A gradual increase in the coordination of propagation of flagellar bending makes the gamete motile and progressive. In species

130 that have been studied, this activation occurs in sperm in the corpus epididymides, after a transitory phase of uncoordinated beating. In humans, this activation occurs in sperm from the distal caput of the epididymis (Fig 6).

Transit of the sperm through the epididymis must be necessary for sperm maturation since sperm maturation has not been achieved in vitro to date. Sperm maturation is probably related to sequential modifications which occur mainly on the sperm surface. During the maturation process, the immature gametes progressively lose or modify most of their testicular surface proteins and gain new transient or permanent proteins in well organized membrane protein domains. The pattern of sperm surface modification is species-specific, related to the nature of the surface proteins involved or the epididymal regions where these 140 modifications occur. However, common changes in several identified sperm surface proteins have been described, e.g. such as fertilin (Primakoff et al., 1988), CRISP1 (Roberts et al., 2006), P34H (Sullivan et al., 2006) and ACE (Gatti et al., 2002), which represent the most important sperm surface changes (Fig 6). Such common changes can also be illustrated by the global surface changes of sialoglycoproteins on the sperm surface in the last part of the epididymis (Dacheux et al., 1989; Dacheux et al., 1987).

Few relationships have been observed between the major sequential modifications of the epididymal proteome and the sequential changes on the sperm surface. Furthermore, there is currently no direct evidence of a specific role for these major proteins, although several of them are known to be enzymes, inhibitors or binding proteins. For several of them, such 
150 as clusterin which is the most common epididymal protein found, gene $\mathrm{KO}$ in mice does not change the fertility of the animals (McLaughlin et al., 2000) .

It is probable that these major epididymal proteins which surround the gametes are more involved in sperm preservation than in inducing specific and localized modifications on the sperm surface. The high concentrations of proteins involved in the protection of gametes from oxidative stress, such as GPX5, thioredoxin peroxidase, glutathione $S$-transferase P, thioredoxin peroxidase and superoxide dismutase, probably contribute to sperm survival during epididymal storage.

However, no more than $10 \%$ of all the proteins present in the epididymal fluid have been identified. The wide range of protein concentrations makes identification of the less highly represented proteins by mass spectrometry more difficult. Furthermore, these unidentified proteins contain the most hydrophobic proteins. These proteins are almost never present in a soluble form in the epididymal luminal fluid but partly associated with membrane structures such as epididymosomes (Frenette et al., 2002; Gatti et al., 2005), or directly transferred to the sperm surface or associated with several binding proteins such as clusterin and several lipocalins (Ecroyd et al., 2005).

\section{Conclusion}

New approaches, including large scale analysis, are now being applied to the study of epididymis physiology and the post-testicular differentiation of spermatozoa. Both transcriptomic (Turner et al., 2006) and proteomic approaches provide a dramatic advance to our understanding of male reproduction in different species. From the first results of these global approaches, it is evident that significant differences exist between species either in the sequential changes in the luminal proteome or sperm surface proteins. Each species appears to have developed its own strategy for sperm maturation and preservation. A general feature of sperm maturation probably exists between mammalians but it probably involves different protein combinations. However, there is a need to identify more epididymal and sperm proteins in order to obtain greater understanding of this aspect of the male reproductive system which is fundamental for the survival of all species. 
1. Castella S., Benedetti H., de Llorens R., Dacheux J.L., Dacheux F., 2004. Train A, an RNase A-like protein without RNase activity, is secreted and reabsorbed by the same epididymal cells under testicular control. Biol Reprod. 71, 1677-87.

2. Clulow J., Jones R.C., Hansen L.A., 1994. Micropuncture and cannulation studies of fluid composition and transport in the ductuli efferentes testis of the rat: comparisons with the homologous metanephric proximal tubule. Exp Physiol. 79, 915-28.

3. Dacheux J.L., Belghazi M., Lanson Y., Dacheux F., 2006. Human epididymal secretome and proteome. Mol Cell Endocrinol. 250, 36-42 .

190 4. Dacheux J.L., Chevrier C., Lanson Y., 1987. Motility and surface transformations of human spermatozoa during epididymal transit. Annals of New York Academy of Sciences. 513, 560-563.

5. Dacheux J.L., Dacheux F., Paquignon M., 1989. Changes in sperm surface membrane and luminal protein fluid content during epididymal transit in the boar. Biol Reprod. 40, 635-51.

6. Dacheux J.L., Gatti J.L., Dacheux F., 2003. Contribution of epididymal secretory proteins for spermatozoa maturation. Microsc Res Tech. 61, 7-17.

7. Dacheux J.L., Paquignon M., Lanneau M., 1984. Sequential analysis of the epididymal sperm maturation process in the boar. Ann N Y Acad Sci. 438, 526-29.

200 8. Druart X., Gatti J.L., Dacheux F., Dacheux J.L., 1994. Analysis by two-dimensional gel electrophoresis of ram epididymal secreted proteins. Cell Mol Biol (Noisy-legrand). 40, 91-93.

9. Ecroyd H., Belghazi M., Dacheux J.L., Gatti J.L., 2005. The epididymal soluble prion protein forms a high-molecular-mass complex in association with hydrophobic proteins. Biochem J. 392, 211-19.

10. Fouchecourt S., Metayer S., Locatelli A., Dacheux F., Dacheux J.L., 2000. Stallion epididymal fluid proteome: qualitative and quantitative characterization; secretion and dynamic changes of major proteins. Biol Reprod. 62, 1790-803.

11. Frenette G., Lessard C., Sullivan R., 2002. Selected proteins of "prostasome-like particles" from epididymal cauda fluid are transferred to epididymal caput spermatozoa in bull. Biol Reprod. 67, 308-13.

12. Gatti J.L., Druart X., Guerin Y., Dacheux F., Dacheux J.L., 1999. A 105- to 94kilodalton protein in the epididymal fluids of domestic mammals is angiotensin Iconverting enzyme (ACE); evidence that sperm are the source of this ACE. Biol Reprod. 60, 937-45.

13. Gatti J.L., Metayer S., Belghazi M., Dacheux F., Dacheux J.L., 2005. Identification, proteomic profiling, and origin of ram epididymal fluid exosome-like vesicles. Biol 
Reprod. 72, 1452-65.

14. Gatti J.L., Metayer S., Moudjou M., Andreoletti O., Lantier F., Dacheux J.L., Sarradin P., 2002. Prion protein is secreted in soluble forms in the epididymal fluid and proteolytically processed and transported in seminal plasma. Biol Reprod. 67, 393400 .

15. Guérin, Y., Locatelli, Y., Comizolli, P., Mauget, R., Mermillod, P., Legendre, X., Gatti, J.L., Dacheux, J.L.2003. Conservation et utilisation du sperme épididymaire d'ovins et de cervidés en insémination artificielle et fécondation in vitro. In: Les Actes du BRG, BRG Publishers, Paris, vol 4, pp. 173-183.

16. Holstein A-F. Morphologische Studien am Nebenhoden des Menschen. Stuttgart: Geortge Thieme Verlag; 1969.

17. Jones RC. 2002. Evolution of the epididymis. In: Robaire B, Hinton BT (eds.), The epididymis from molecules to clinical practice. A comprehensive survey of the efferent ducts, the epididymis and the vas deferens. Kluwer Academic-Plenum Publishers, New York, London: pp. 11-33.

18. Jones R.C., 1999. To store or mature spermatozoa? The primary role of the epididymis. Int J Androl. 22, 57-67.

19. Jones R.C., Dacheux J.L., Nixon B., Ecroyd H.W., 2007. Role of the epididymis in sperm competition. Asian J Androl. 9, 493-99.

20. McLaughlin L., Zhu G., Mistry M., Ley-Ebert C., Stuart W.D., Florio C.J., Groen P.A., Witt S.A., Kimball T.R., Witte D.P., Harmony J.A., Aronow B.J., 2000. Apolipoprotein $\mathrm{J} /$ clusterin limits the severity of murine autoimmune myocarditis. $\mathrm{J}$ Clin Invest. 106, 1105-13.

21. Metayer S., Dacheux F., Dacheux J.L., Gatti J.L., 2002. Germinal angiotensin Iconverting enzyme is totally shed from the rodent sperm membrane during epididymal maturation. Biol Reprod. 67, 1763-67.

22. Primakoff P., Lathrop W., Woolman L., Cowan A., Myles D., 1988. Fully effective contraception in male and female guinea pigs immunized with the sperm protein $\mathrm{PH}-$ 20. Nature. 335, 543-6.

23. Roberts K.P., Ensrud K.M., Wooters J.L., Nolan M.A., Johnston D.S., Hamilton D.W., 2006. Epididymal secreted protein Crisp-1 and sperm function. Mol Cell Endocrinol. 250, 122-7.

24. Sullivan R., Legare C., Villeneuve M., Foliguet B., Bissonnette F., 2006 . Levels of $\mathrm{P} 34 \mathrm{H}$, a sperm protein of epididymal origin as a predictor of conventional in vitro fertilization outcome. Fertil Steril.85, 1557-59

25. Syntin P., Dacheux F., Druart X., Gatti J.L., Okamura N., Dacheux J.L., 1996. Characterization and identification of proteins secreted in the various regions of the adult boar epididymis. Biol Reprod. 55, 956-74.

26. Thimon V., Metayer S., Belghazi M., Dacheux F., Dacheux J.L., Gatti J.L., 2005. Shedding of the germinal angiotensin I-converting enzyme (gACE) involves a serine 
protease and is activated by epididymal fluid. Biol Reprod. 73, 881-90.

27. Turner T.T., Johnston D.S., Jelinsky S.A., 2006. Epididymal genomics and the search for a male contraceptive. Mol Cell Endocrinol. 250, 178-83.

28. Turner T.T., Miller D.W., Avery E.A., 1995. Protein synthesis and secretion by the rat caput epididymidis in vivo: influence of the luminal microenvironment. Biol Reprod. 52, 1012-9.

29. Turner T.T., Riley T.A., Mruk D.D., Cheng C.Y., 1999. Obstruction of the vas deferens alters protein secretion by the rat caput epididymidal epithelium in vivo. $\mathrm{J}$ Androl. 20, 289-97. 


\section{Legends of the figures:}

270 Figure 1: Spermatocrit (A), protein secretion (B) and concentrations of luminal proteins (C) in the epididymal fluid from 9 regions of the epididymis (1-4: caput; 5-6: corpus; 7-9: cauda) for three species (ram, boar, stallion) from (Syntin et al., 1996; Fouchecourt et al., 2000) and unpublished data.

Figure 2: Epididymal secretomes and proteomes of four species. For proteomes, each plate corresponds to $1 \mathrm{D}$ gel electrophoresis separation of about the same quantity of epididymal protein from each region of the epididymis. The secretome diagrams represent each secreted protein from the different epididymal regions and are expressed as the percentage of total secretion of the whole organ. The plates illustrating the secretory activities of the different epididymal regions for the four animal species correspond to the autoradiograms of the same four 1D gel separations presented above for the proteome (Syntin et al., 1996; Fouchecourt et al., 2000 ; Druart et al., 1994 ; Druart, unpublished data ; Dacheux et al., 2006).

Figure 3: Immunodetection of 2D electrophoresis gels of isoforms of three proteins (PGDS, clusterin and RNase 10) according to their epididymal and species origins (stallion: Fouchecourt et al., 2000; boar: Castella et al., 2004 and ram: unpublished data).

Figure 4: Distribution of the major proteins secreted by the human and boar epididymis (Dacheux et al., 2006; Syntin et al., 1996)

290 Figure 5: Relationship between secretome and proteome. A) Secretion and protein concentrations for five major proteins present in the epididymal fluid of the stallion. B) Epididymal localisation of the secretion, luminal protein and corresponding RNA of RNase 10 (Train A) from the initial segment (IS), caput (1-4), corpus (5-6), cauda (7-9) in the boar (Castella et al., 2004).

Figure 6: Sperm epididymal maturation according to epididymal region in the human (Dacheux et al., 1987) and porcine (Dacheux et al., 1984) related to ACE, sialoprotein modifications on the sperm surface and percentage of progressive motility along the epididymis. 


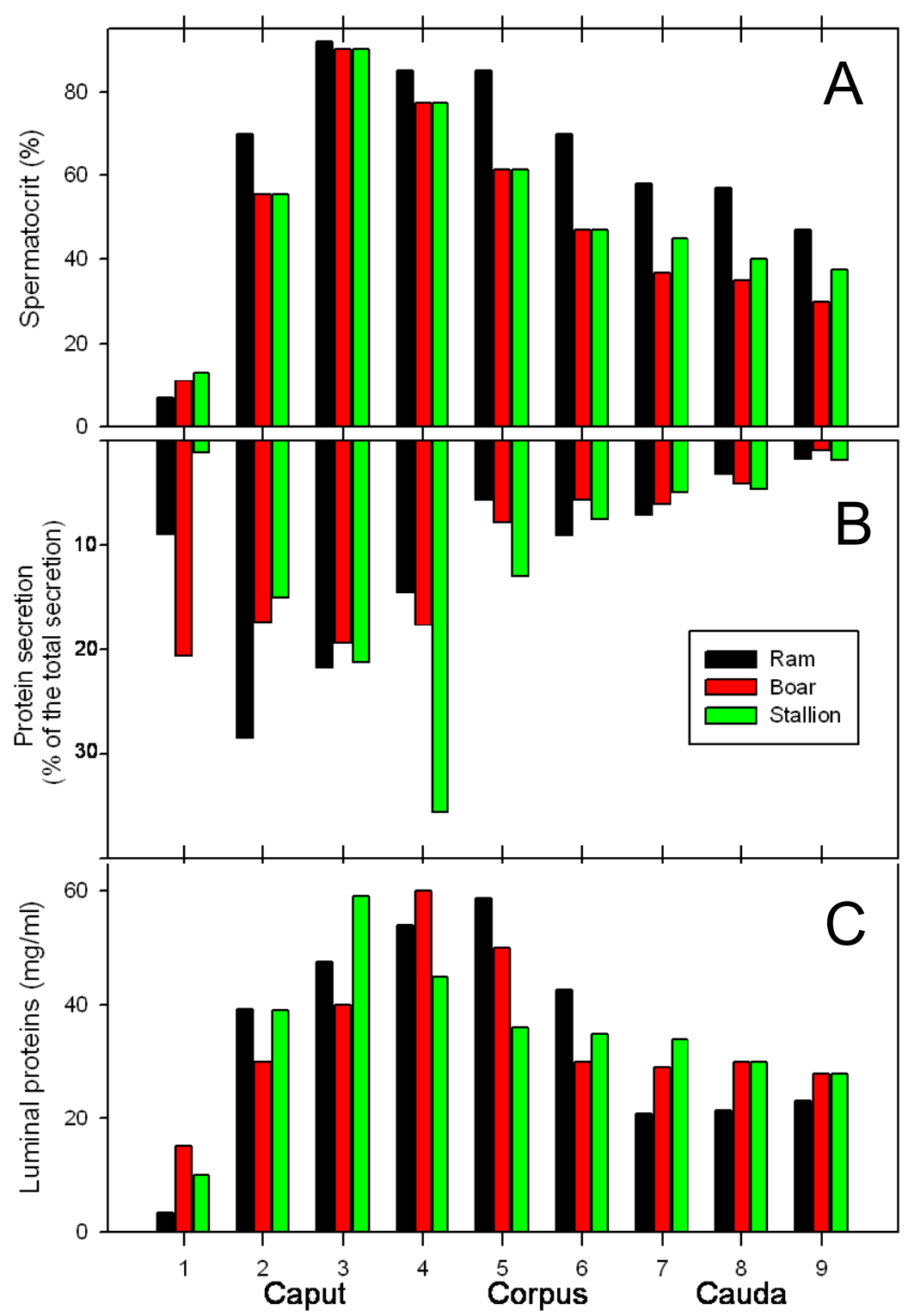

Epididymal Regions

Figure 1 


\section{Porcine \\ Equine \\ Ovine \\ Human}
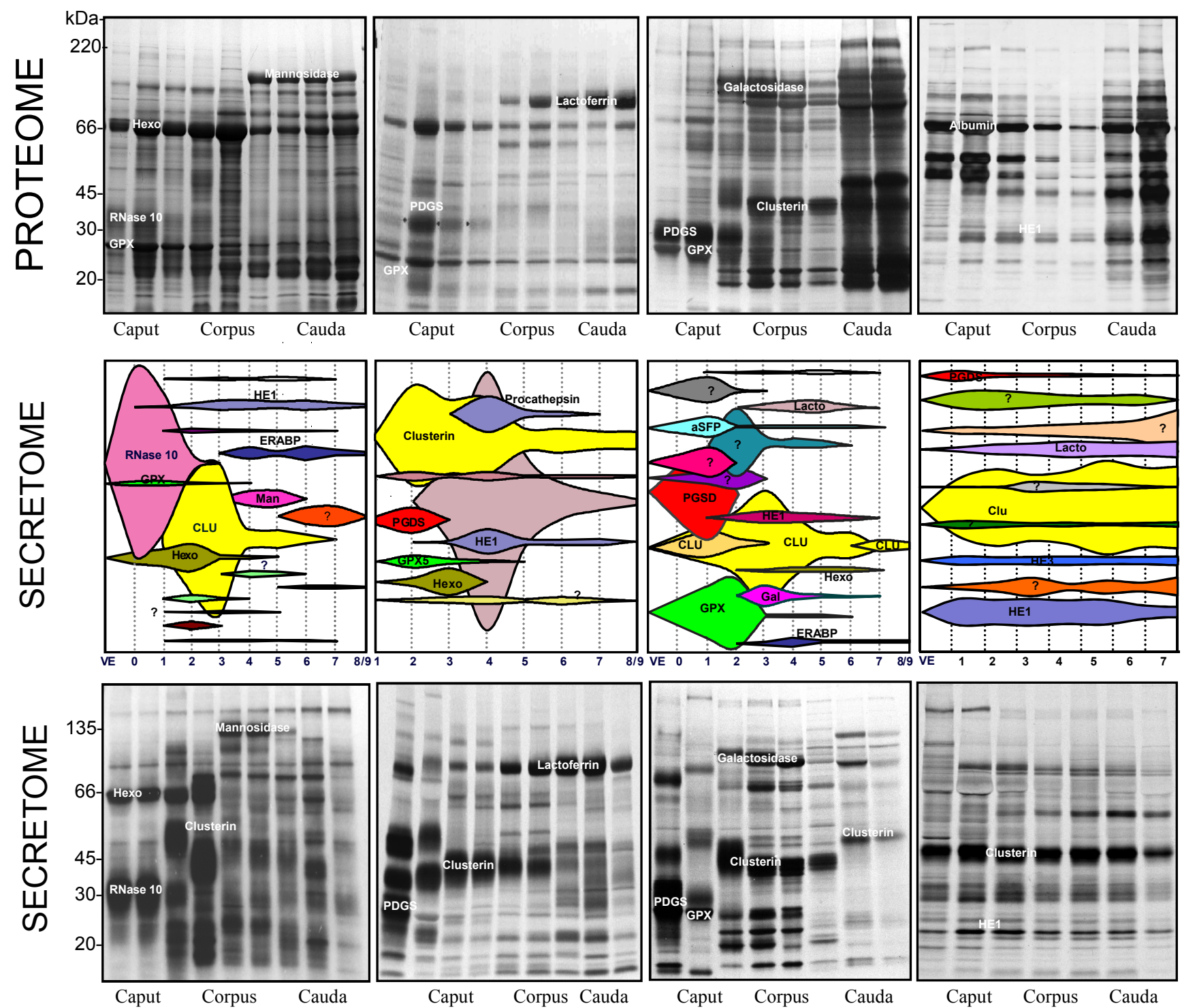

Figure 2 


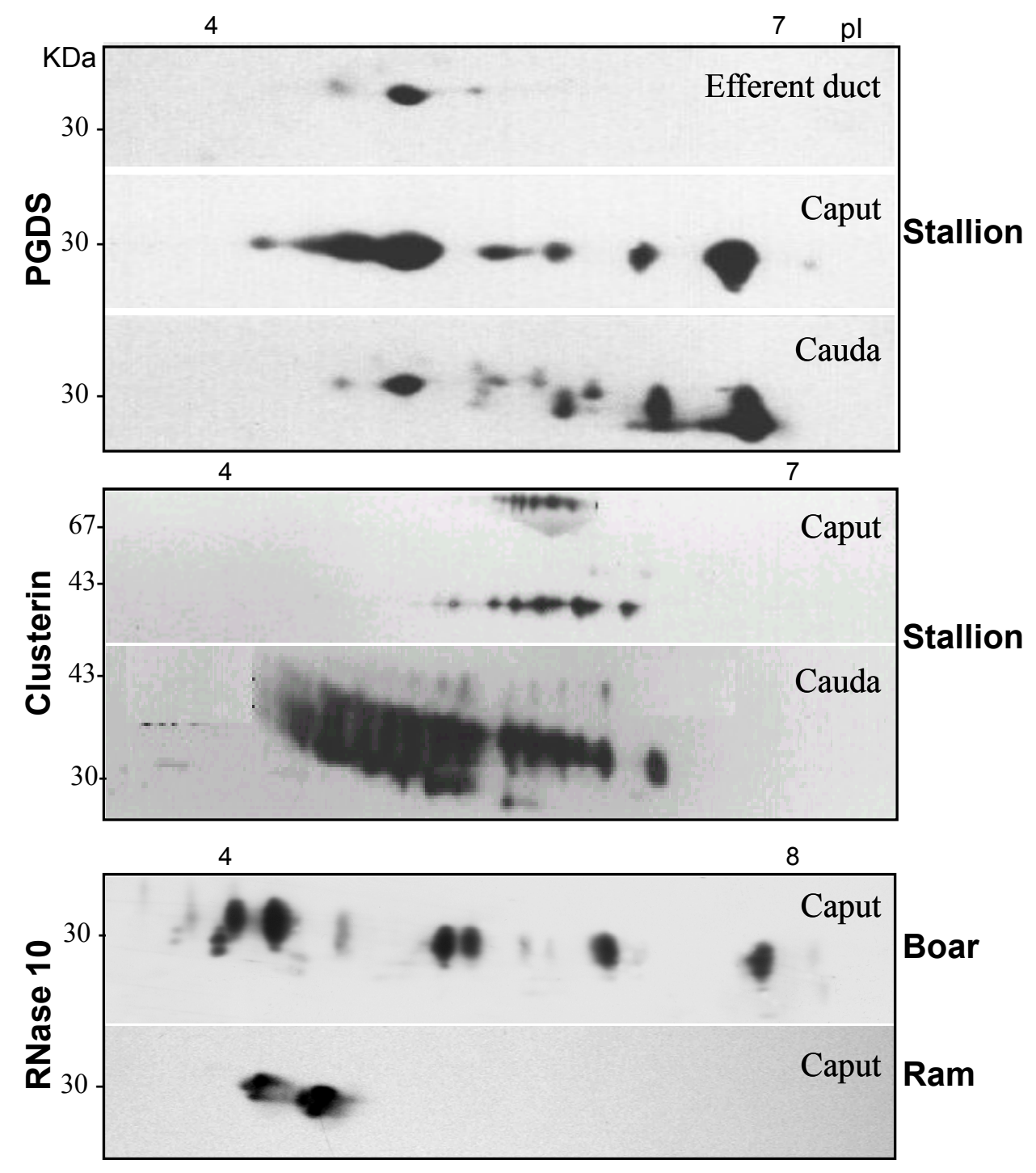

Figure 3 


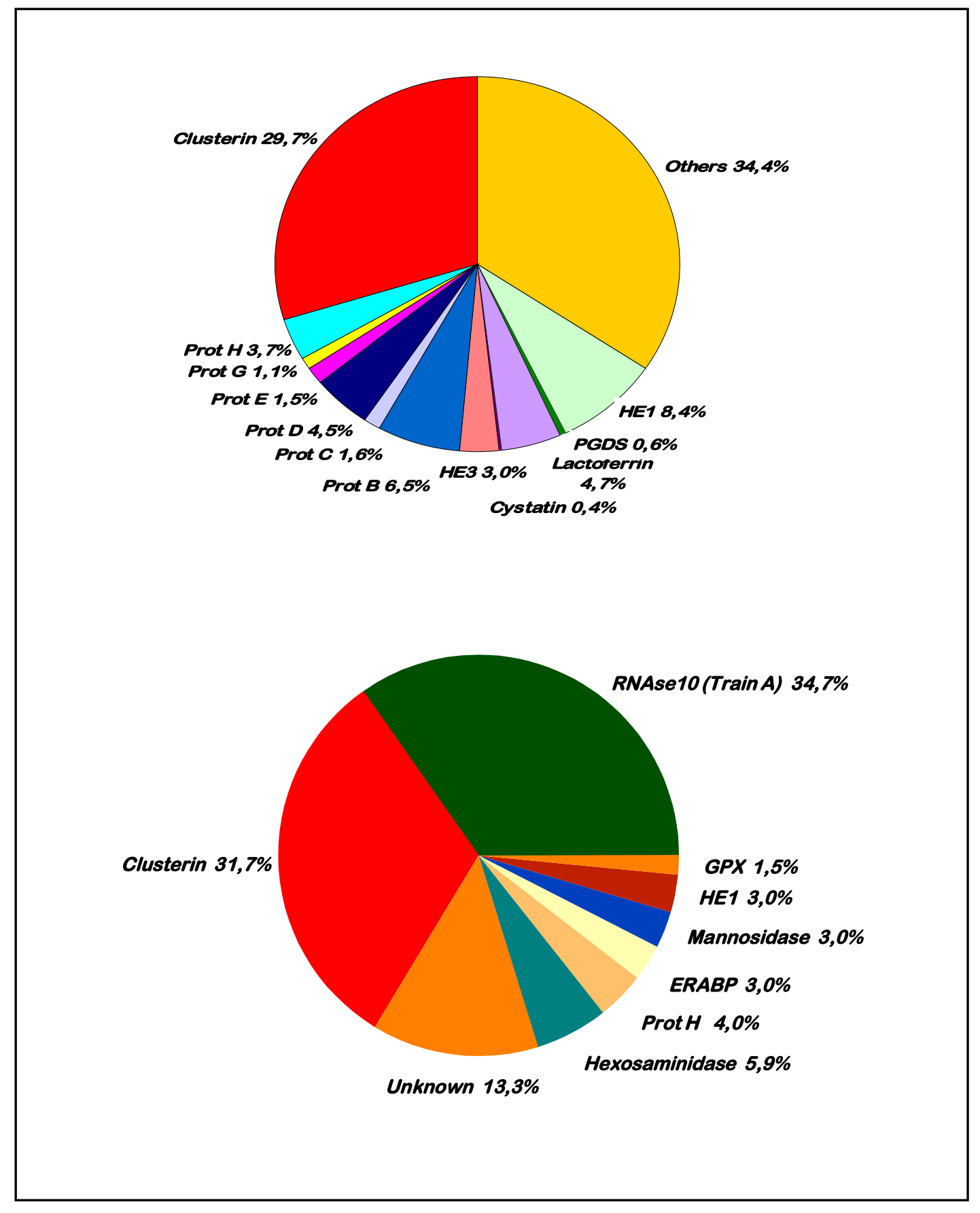



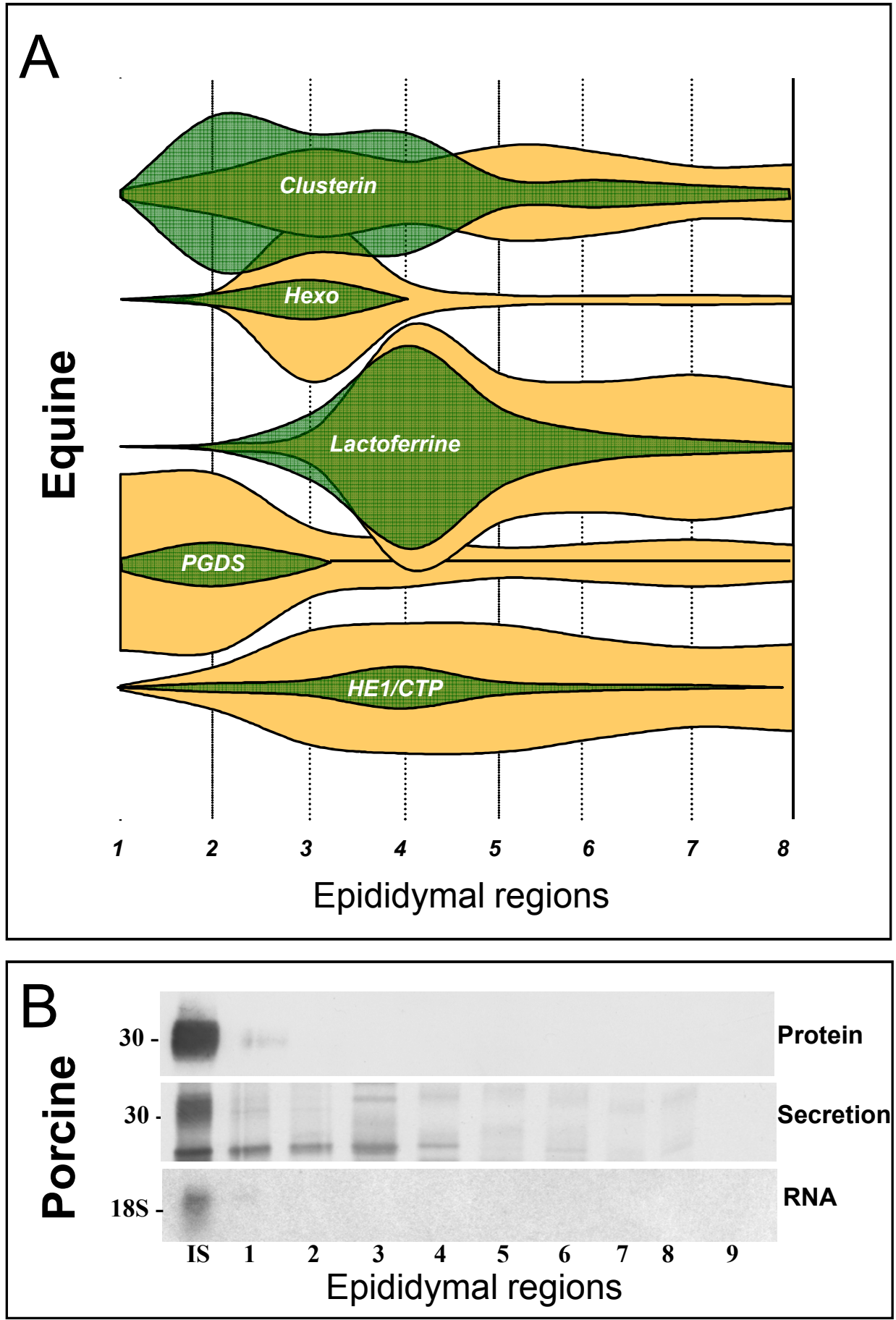

Figure 5 


\section{Human}

\section{Porcine}
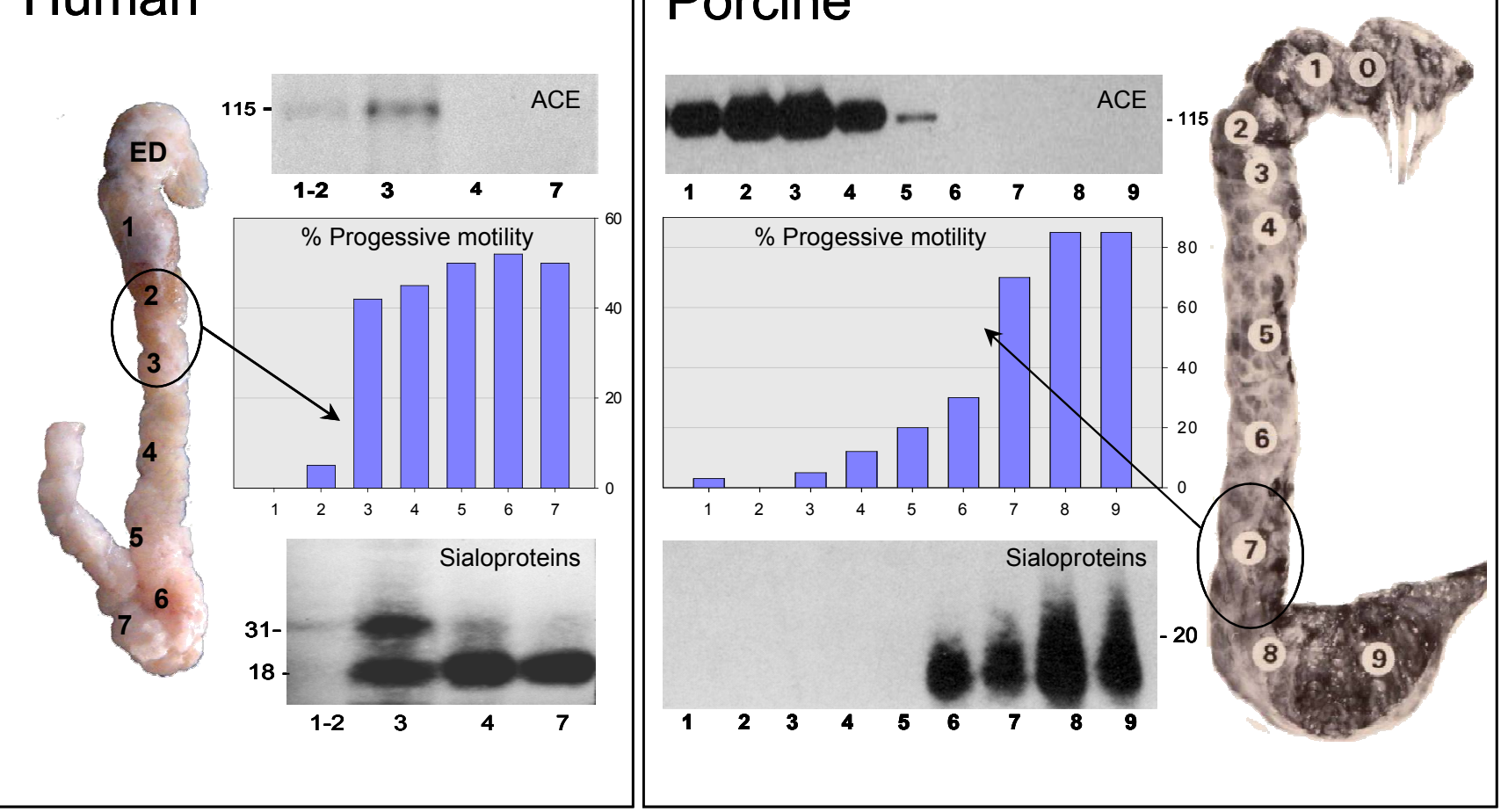

Figure 6 